\title{
Association of C- Reactive Protein and HbA1c in the Severity of Coronary Artery Disease in Patients with Ischemic Heart Disease
}

\author{
Mohsin Ahmed ${ }^{1}$, Md Mesbahul Islam² ${ }^{2}$ Mohammad Arifur Rahman ${ }^{1}$, Khandaker Abu Rubaiyat ${ }^{3}$, \\ C. M Khudrate-E-Khuda ${ }^{3}$, Kazi Abul Fazal Ferdous ${ }^{3}$, Bikash Chandra Das ${ }^{3}$, \\ Mahmudul Hasan ${ }^{1}$, Mizanur Rahman Majumder ${ }^{1}$ \\ ${ }^{1}$ Department of Cardiology, National Institute of Cardiovascular Diseases, Dhaka ${ }^{2}$ Department of \\ Cardiology, IBN SINA specialized Hospital, Dhanmondi, Dhaka, ${ }^{3}$ Department of Cardiology, \\ Dhaka Medical College Hospital, Dhaka
}

\begin{abstract}
Keywords: Coronary artery disease, $C$ reactive protein, $H b A 1 c$

Background: C-reactive protein (CRP) and glycohemoglobin (HbA1c) are established risk factors for the development of cardiovascular disease. We investigated the joint effects of these parameters on the severity of coronary artery disease (CAD) in patients with ischemic heart disease.

Methods: This cross sectional study was performed on 668 patients of ischemic heart disease. CRP value were divided into normal $(<6 \mathrm{mg} / \mathrm{L})$, borderline $(6-10 \mathrm{mg} / \mathrm{L})$ and high $(>10 \mathrm{mg} / \mathrm{L})$ and $\mathrm{HbAlc}$ was divided $<6.5 \%$ and $\geq 6.5 \%$. After performing Coronary angiography the extent of disease was divided into insignificant $C A D$ of ( $<50 \%$ stenosis), significant CAD considered as $>50 \%$ stenosis and single vessel, double vessel, triple vessel $C A D$ and normal coronaries.

Results: Most (65.0\%) of the patients belonged to age 41-60 years. The mean age was found 51.4 \pm 10.7 years. Majority (82.3\%) of patients were male. Among risk factors, highest (40.0\%) patients had hypertension followed by 209 (31.3\%) diabetes mellitus and 204 (30.5\%) smoker. The relationship of CRP with the whole spectrum of ischemic heart disease was found statistically significant $(p<0.05)$. The relationship of HbA1c and CRP were significantly associated with the severity of coronary artery disease. At HbA1c e"6.5 percent, severe CAD (double vessel and triple vessel) were found higher in high CRP than normal and borderline CRP group.

Conclusion: Inflammation, presented by CRP, and hyperglycemia, presented by HbA1c, jointly contributes to the cardiovascular risk of patients. Patients with high CRP and elevated HbA1c are associated with severe coronary artery diseases.
\end{abstract}

(Cardiovasc. j. 2018; 11(1): 53-58)

\section{Introduction:}

Despite important advances in the diagnosis and treatment of coronary artery disease, it is still among the most common causes of death and disability in the world, which endangers global health. Coronary artery disease (CAD) is the principal cause of disability and mortality worldwide, and its prevalence is increasing around the world. ${ }^{1}$ Factors such as age, diabetes, lipid profile, smoking, gender and heredity are introduced as risk factors for coronary artery disease. $^{2,3}$ In recent decades, the inflammatory idea of atherosclerosis has been strongly suggested and hence the measurement of inflammatory marker's levels to determine the risk of cardiovascular events. ${ }^{4,6}$
C-reactive protein (CRP), a marker of systemic inflammation, is emerging as an independent risk factor for cardiovascular disease. ${ }^{7-9}$ High CRP levels have been linked to an increased risk of thrombotic events including myocardial infarction. ${ }^{9-11}$. Elevated CRP levels have also been linked to an increased risk of later development of diabetes. ${ }^{12,13}$ Furthermore, CRP levels are higher in people with diabetes compared with those without diabetes. ${ }^{14-16}$ To provide further insight into the role of inflammation in the development we sought to elucidate the link between level of glycemic control and inflammation using a representative sample. Elevated glycohemoglobin A1 (HbA1c) is an established predictor for developing

Address of Correspondence: Dr. Mohsin Ahmed, Department of Cardiology, National Institute of Cardiovascular Diseases, Dhaka, Bangladesh. Email: mohsinsohe107@gmail.com 
atherosclerosis. ${ }^{17,18}$ Eeg-Olofsson et al. ${ }^{19}$ studied a total of 7,454 patients from the Swedish National Diabetes Register over a period of 5 years (aged 20-65 years, diabetes duration 1-35 years) and found a progressively increasing risk of coronary heart disease and cardiovascular diseases with higher $\mathrm{HbA1c}$ levels independent of traditional risk factors. HbA1c is a better marker for determining risks of $\mathrm{CAD}$ and mortality than fasting blood glucose and even non-diabetic patients with elevated HbA1c levels are also at increased risk for CVD and mortality. ${ }^{20}$ Both enhanced inflammation and hyperglycemia contribute to the development and progression of atherosclerosis and are frequently found in patients with clinically advanced disease.

Given the interrelation between inflammation, hyperglycemia, and atherosclerotic disease, we speculated that CRP and HbA1c jointly contribute to the cardiovascular risk of patients with clinically advanced atherosclerotic disease.

\section{Methods:}

This cross sectional study was performed on 668 patients of ischemic heart disease (CSA, UA, NSTEMI and STEMI) in the Department of Cardiology, Dhaka Medical College Hospital, Dhaka, who were underwent Coronary angiography from January 2017 to December 2017. The patients' demographic variables, such as age and sex, west and hip circumference and angiography results were recorded. After explaining the aims of the study and obtaining the patient's approval for participation blood samples were sent. CRP value were divided into normal $(<6 \mathrm{mg} / \mathrm{L})$, borderline $(6-10 \mathrm{mg} / \mathrm{L})$ and high $(>10 \mathrm{mg} / \mathrm{L})^{21}$ and $\mathrm{HbA} 1 \mathrm{c}$ was divided $<6.5 \%$ and $\geq 6.5 \%$. After performing Coronary angiography the extent of disease was divided into insignificant CAD of $(<50 \%$ stenosis), significant CAD considered as $>50 \%$ stenosis and single vessel, double vessel, triple vessel CAD and normal coronaries. The relationship between CRP and HbA1c with the severity of CAD was recorded by Chi square test. Statistical Package for the Social Sciences (SPSS) version 23.0 for windows was used to analyze the data. Categorical variables were expressed as proportions (percentages) and numerical data was expressed as means (standard deviations) and ranges. $p$ value $<0.05$ was considered as statistically significant.

\section{Results:}

This cross sectional study was performed on 668 patients of ischemic heart disease (CSA, UA, NSTEMI and STEMI) in the Department of Cardiology, Dhaka Medical College Hospital, Dhaka, who were underwent Coronary angiography from January 2017 to December 2017.

Most (65.0\%) of the patients belonged to age 4160 years. The mean age was found $51.4 \pm 10.7$ years with range from 25-85 years. Majority (82.3\%) patients were male and $390(58.4 \%)$ patients were illiterate (Table-I). In risk factors, highest (40.0\%) patients had hypertension followed by 209 (31.3\%) diabetes mellitus, 204 (30.5\%) smoker, 189 (28.3\%) family history of ischemic heart disease and 151 (22.6\%) dyslipidemia (Table-II). The relationship of $\mathrm{HbA1c}$ with the whole spectrum of ischemic heart disease was not statistically significant $(p>0.05)$ but the relationship of CRP with the whole spectrum of ischemic heart disease was statistically significant $(p<0.05)$. Both the relationship of HbA1c and CRP were significantly associated with the severity of coronary artery disease (Table-V). At HbA1c e"6.5 percent, severe CAD (double vessel and triple vessel) were found higher in high CRP than normal and borderline CRP group. Which were statistically significant $(\mathrm{p}<0.05)$ (Table-VII).

Table-I

Demographic characteristics of the study subjects $(n=668)$.

\begin{tabular}{lcc}
\hline $\begin{array}{l}\text { Demographic } \\
\text { characteristics }\end{array}$ & Frequency & Percentage \\
\hline Age (in years) & & \\
$\quad \leq 40$ & 123 & 18.4 \\
$41-60$ & 434 & 65.0 \\
$\quad>60$ & 111 & 16.6 \\
Mean \pm SD & $51.4 \pm 10.7$ & \\
Range (min-max) & $(25-85)$ & \\
Sex & & \\
$\quad$ Male & 550 & 17.7 \\
$\quad$ Female & 118 & \\
Educational status & & 58.4 \\
$\quad$ Illiterate & 390 & 16.5 \\
$\quad$ Primary & 110 & 16.6 \\
$\quad$ Secondary & 111 & 5.5 \\
$\quad$ Higher & 37 & 3.0 \\
$\quad$ Graduate and above & 20 & \\
\hline
\end{tabular}


Table-II

Distribution of the study subjects by clinical risk factors $(n=668)$.

\begin{tabular}{lcc}
\hline Risk factors & Frequency & Percentage \\
\hline Diabetes mellitus & 209 & 31.3 \\
Hypertension & 267 & 40.0 \\
Dyslipidemia & 151 & 22.6 \\
Obesity & 28 & 4.2 \\
Smoking & 204 & 30.5 \\
Tobacco & 97 & 14.5 \\
Alcohol & 2 & 0.3 \\
Family history of CAD & 31 & 4.6 \\
H/O ischemic heart disease & 189 & 28.3 \\
Previous PTCA & 11 & 1.6 \\
Previous CABG & 10 & 1.5 \\
\hline
\end{tabular}

Table-III

Relationship of HbA1c with clinical spectrum of ischemic heart disease.

\begin{tabular}{lccc}
\hline Diagnosis & \multicolumn{2}{c}{ HbA1c (\%) } & $\mathrm{p}$ value \\
\cline { 2 - 3 } & $<6.5(\mathrm{n}=359)$ & $\geq 6.5(\mathrm{n}=309)$ & \\
\hline Chronic stable angina & $94(26.2 \%)$ & $\mathrm{n}(\%)$ & $0.902^{\mathrm{ns}}$ \\
Unstable angina & $69(19.2 \%)$ & $60(19.4 \%)$ & \\
NSTEMI & $41(11.4 \%)$ & $32(10.4 \%)$ & \\
STEMI & $155(43.2 \%)$ & $129(41.7 \%)$ & \\
\hline
\end{tabular}

Data were analyzed by Chi-square test, $\mathrm{ns}=$ not significant

Table-IV

Relationship of CRP with clinical spectrum of ischemic heart disease.

\begin{tabular}{lcccc}
\hline Diagnosis & \multicolumn{3}{c}{ CRP } & p value \\
\cline { 2 - 4 } & $\begin{array}{c}\text { Normal } \\
(<6 \mathrm{mg} / \mathrm{L})\end{array}$ & $\begin{array}{c}\text { Borderline } \\
(6-10 \mathrm{mg} / \mathrm{L})\end{array}$ & $\begin{array}{c}\text { High } \\
(>10 \mathrm{mg} / \mathrm{L})\end{array}$ & \\
& $(\mathrm{n}=56) \mathrm{n}(\%)$ & $(\mathrm{n}=287) \mathrm{n}(\%)$ & $(\mathrm{n}=325) \mathrm{n}(\%)$ & $0.032^{\mathrm{s}}$ \\
\hline Chronic stable angina & $21(37.5 \%)$ & $86(30.0 \%)$ & $75(23.1 \%)$ & \\
Unstable angina & $6(10.7 \%)$ & $51(17.8 \%)$ & $72(22.2 \%)$ & \\
NSTEMI & $3(5.4 \%)$ & $26(9.1 \%)$ & $44(13.5 \%)$ & \\
STEMI & $26(46.4 \%)$ & $124(43.2 \%)$ & $134(41.2 \%)$ & \\
\hline
\end{tabular}

Data were analyzed by Chi-square test, $\mathrm{s}=$ significant

Table-V

Relationship of HbA1c with extent of disease.

\begin{tabular}{|c|c|c|c|}
\hline \multirow[t]{2}{*}{ Extent of disease } & \multicolumn{2}{|c|}{ HbA1c (\%) } & \multirow[t]{2}{*}{$\mathrm{p}$ value } \\
\hline & $<6.5(\mathrm{n}=359) \mathrm{n}(\%)$ & $\geq 6.5(\mathrm{n}=309) \mathrm{n}(\%)$ & \\
\hline Single vessel & $125(34.8 \%)$ & $96(31.1 \%)$ & $0.032^{\mathrm{s}}$ \\
\hline Double vessel & $78(21.7 \%)$ & $88(28.5 \%)$ & \\
\hline Triple vessel & $95(26.5 \%)$ & $94(30.4 \%)$ & \\
\hline Normal coronaries & $52(14.5 \%)$ & $26(8.4 \%)$ & \\
\hline Insignificant CAD & $9(2.5 \%)$ & $5(1.6 \%)$ & \\
\hline
\end{tabular}

Data were analyzed by Chi-square test, $\mathrm{s}=$ significant 
Table-VI

Relationship of high CRP with extent of coronary artery diseases.

\begin{tabular}{lcccc}
\hline Extent of diseases & \multicolumn{3}{c}{ CRP } & p value \\
\cline { 2 - 4 } & $\begin{array}{c}\text { Normal } \\
(<6 \mathrm{mg} / \mathrm{L})\end{array}$ & $\begin{array}{c}\text { Borderline } \\
(6-10 \mathrm{mg} / \mathrm{L})\end{array}$ & $\begin{array}{c}\text { High } \\
(>10 \mathrm{mg} / \mathrm{L})\end{array}$ & \\
& $(\mathrm{n}=56) \mathrm{n}(\%)$ & $106(36.9 \%)$ & $91(28.0 \%)$ & $0.001^{\mathrm{s}}$ \\
Single vessel & $24(42.9 \%)$ & $52(18.1 \%)$ & $106(32.6 \%)$ & \\
Double vessel & $8(14.3 \%)$ & $64(22.3 \%)$ & $116(35.7 \%)$ & \\
Triple vessel & $9(16.1 \%)$ & $60(20.9 \%)$ & $3(0.9 \%)$ & \\
Normal coronaries & $15(26.8 \%)$ & $5(1.7 \%)$ & $9(2.8 \%)$ & \\
Insignificant CAD & $0(0.0 \%)$ & &
\end{tabular}

Data were analyzed by Chi-square test, $\mathrm{s}=$ significant

Table-VII

Association of extent of coronary artery disease with both HbAlc and CRP.

\begin{tabular}{|c|c|c|c|c|c|}
\hline \multirow[t]{2}{*}{ Diagnosis } & \multirow{2}{*}{$\begin{array}{c}\text { HbA1c } \\
(\%)\end{array}$} & \multicolumn{3}{|c|}{$\mathrm{CRP}$} & \multirow[t]{2}{*}{$\mathrm{p}$ value } \\
\hline & & $\begin{array}{c}\text { Normal } \\
(<6 \mathrm{mg} / \mathrm{L}) \\
(\mathrm{n}=56) \mathrm{n}(\%)\end{array}$ & $\begin{array}{l}\text { Borderline } \\
(6-10 \mathrm{mg} / \mathrm{L}) \\
(\mathrm{n}=287) \mathrm{n}(\%)\end{array}$ & $\begin{array}{c}\text { High } \\
(>10 \mathrm{mg} / \mathrm{L}) \\
(\mathrm{n}=325) \mathrm{n}(\%)\end{array}$ & \\
\hline \multirow[t]{2}{*}{ Single vessel } & $<6.5$ & $14(58.3 \%)$ & $63(59.4 \%)$ & $48(52.7 \%)$ & \multirow[t]{2}{*}{$0.630^{\mathrm{ns}}$} \\
\hline & $\geq 6.5$ & $10(41.7 \%)$ & $43(40.6 \%)$ & $43(47.3 \%)$ & \\
\hline \multirow[t]{2}{*}{ Double vessel } & $<6.5$ & $4(50.0 \%)$ & $37(71.2 \%)$ & $37(34.9 \%)$ & \multirow[t]{2}{*}{$0.001^{\mathrm{s}}$} \\
\hline & $\geq 6.5$ & $4(50.0 \%)$ & $15(28.8 \%)$ & $69(65.1 \%)$ & \\
\hline \multirow[t]{2}{*}{ Triple vessel } & $<6.5$ & $6(66.7 \%)$ & $43(67.2 \%)$ & $46(39.7 \%)$ & \multirow[t]{2}{*}{$0.001^{\mathrm{s}}$} \\
\hline & $\geq 6.5$ & $3(33.3 \%)$ & $21(32.8 \%)$ & $70(60.3 \%)$ & \\
\hline \multirow{2}{*}{ Normal coronary arteries } & $<6.5$ & $9(60.0 \%)$ & $42(70.0 \%)$ & $1(33.3 \%)$ & \multirow[t]{2}{*}{$0.350^{\mathrm{ns}}$} \\
\hline & $\geq 6.5$ & $6(40.0 \%)$ & $18(30.0 \%)$ & $2(66.7 \%)$ & \\
\hline \multirow[t]{2}{*}{ Insignificant CAD } & $<6.5$ & $0(0.0 \%)$ & $3(60.0 \%)$ & $6(66.7 \%)$ & \multirow[t]{2}{*}{$0.803^{\text {ns }}$} \\
\hline & $\geq 6.5$ & $0(0.0 \%)$ & $2(40.0 \%)$ & $3(33.5 \%)$ & \\
\hline
\end{tabular}

Data were analyzed by Chi-square test, $\mathrm{s}=$ significant, $\mathrm{ns}=$ not significant

\section{Discussion:}

The objective of this study was to identify the CRP as a definite inflammation marker and $\mathrm{HbA} 1 \mathrm{c}$ in estimating coronary lesions in patients with the whole spectrum of ischemic heart disease. Although atherosclerosis was formerly considered a bland lipid storage disease, substantial advances in basic and clinical studies have illuminated the role of inflammation and the underlying cellular and molecular mechanisms that contribute to atherogenesis. ${ }^{4,23,24}$ In this context, accumulating epidemiological data evolved indicating that elevation of CRP heralds atherothrombotic events. ${ }^{25-28}$

In this present study it was observed that most (65.0\%) of the patients belonged to age 41-60 years. The mean age was found $51.4 \pm 10.7$ years with range from 25-85 years. Majority (82.3\%) patients were male and $390(58.4 \%)$ patients were illiterate. Similar observation also found by Razban et al. ${ }^{29}$ and Muhammad et al. ${ }^{30}$

In this study, among the risk factors, highest $267(40.0 \%)$ patients had hypertension followed by 209 (31.3\%) diabetes mellitus, 204 (30.5\%) smoker, 189 (28.3\%) family history of ischemic heart disease and 151 (22.6\%) dyslipidemia. This findings were also consistent with others studies. ${ }^{29-31}$

In this study out of 668 patients, 182 (27.2\%) patients had chronic stable angina, 129 (19.3\%) had unstable angina, 73 (10.9\%) had NSTEMI and 284(42.5\%) had STEMI. The relationship of CRP with the whole spectrum of ischemic heart 
disease was found statistically significant $(p<0.05)$ but the relationship of HbA1c was not statistically significant $(p>0.05)$. Berk et al. ${ }^{32}$ and Liuzzo et al. ${ }^{33}$ have found that serum levels of hs-CRP increased in both groups of patients with stable angina and unstable angina and this marker is considered as a reliable indicator to predicting future events in these patients. Seyedian et al. ${ }^{31}$ also found higher CRP in the unstable angina than stable angina group.

In this study it was observed that the relationship of CRP and HbA1c were significantly associated with the severity of coronary artery disease. Similar result also observed by Haverkate et al. ${ }^{34}$; Tataru et al. ${ }^{35}$; Masood et al. ${ }^{36}$ and Lee et al. ${ }^{22}$

This study observed that at HbA1c e"6.5 percent, severe CAD (double vessel and triple vessel) were found higher in high CRP than normal and borderline CRP, which were statistically significant $(\mathrm{p}<0.05)$ and normal coronary artery, in significant $\mathrm{CAD}$ and single vessel disease were found non significant. Schillinger et al. ${ }^{37}$ reported that hs-CRP and HbA1c jointly as prognostic parameters may help to more adequately identify and better treat highest-risk patients with atherosclerosis.

\section{Conclusion:}

Inflammation, presented by CRP and hyperglycemia, presented by HbA1c, jointly contribute to the cardiovascular risk of patients. Patients with high CRP and elevate HbA1c combinedly associated with severe coronary artery diseases.

\section{Conflict of Interest - None.}

\section{References:}

1. Sayols-Baixeras S, Lluís-Ganella C, Lucas G, Elosua R. Pathogenesis of coronary artery disease: focus on genetic risk factors and identification of genetic variants. Appl Clin Genet 2014;7:15-32.

2. Ridker PM, Libby P, Buring JE. Risk markers and the primary prevention of cardiovascular disease. In: Zipes DP, Libby P, Bonow RO, Mann DL, Tomaselli GF, Braunwald E. Eds. Heart disease: a text book of cardiovascular medicine. 11th ed. Philadelphia: Elsevier; 2018:876-905.

3. Rashidinejad H, Moazanzadeh M, Mirshekarpoor H, Ebrahimi F. The relationship between HS-CRP serum levels with the results of cardiac perfusion SPECT imaging in patients with suspected coronary artery disease. Asian $J$ Biomed Pharm Sci 2015; 5(50):30-33.

4. Ross R. Atherosclerosis-an inflammatory disease. N Engl J Med 1999; 340: 115-126.

5. Blake GJ, Rifai N, Buring JE, Ridker PM. Blood pressure, C-reactive protein, and risk of future cardiovascular events. Circulation 2003; 108: 2993-2999.

6. Albert CM, Ma J, Rifai N, Stampfer MJ, Ridker PM. Prospective study of C-reactive protein, homocysteine, and plasma lipid levels as predictors of sudden cardiac death. Circulation 2002; 105(22):2595-2599.

7. Abdelmouttaleb I, Danchin N, Ilardo C, Aimone-Gastin I, Angioi M, Lozniewski A, et al. C-reactive protein and coronary artery disease: additional evidence of the implication of an inflammatory process in acute coronary syndromes. Am Heart J 1999; 137: 346-351.

8. Ridker PM, Rifai N, Lowenthal SP. Rapid reduction of Creactive protein with cerivastatin among 785 patients with primary hypercholesterolemia. Circulation 2001; 103: 11911193.

9. Ridker PM, Glynn RJ, Hennekens CH. Creactive protein adds to the predictive value of total and HDL cholesterol in determining risk of first myocardial infarction. Circulation 1998; 97: 2007-2011.

10. Kervinen H, Palosuo T, Manninen V, Tenkanen L, Vaarala O, Manttari M. Joint effects of C-reactive protein and other risk factors on acute coronary events. Am Heart J 2001;141: 580-585.

11. Ridker PM, Stampfer MJ, Rifai N. Novel risk factors for systemic atherosclerosis: a comparison of C-reactive protein, fibrinogen, homocysteine, lipoprotein(a), and standard cholesterol screening as predictors of peripheral arterial disease. JAMA 2001;285:2481-2485.

12. Pradhan AD, Manson JE, Rifai N, Buring JE, Ridker PM. C-reactive protein, interleukin- 6 , and risk of developing type 2 diabetes mellitus. JAMA 2001; 286: 327-334.

13. Barzilay JI, Abraham L, Heckbert SR, Cushman M, Kuller $\mathrm{LH}$, Resnick HE, et al. The relation of markers of inflammation to the development of glucose disorders in the elderly: the Cardiovascular Health Study. Diabetes 2001; 50: 2384-2389.

14. Ford ES. Body mass index, diabetes, and C-reactive protein among U.S. Adults. Diabetes Care 1999;22:197-1977.

15. Grau AJ, Buggle F, Becher H, Werle E, Hacke W. The association of leukocyte count, fibrinogen and C-reactive protein with vascular risk factors and ischemic vascular diseases. Thromb Res 1996; 82: 245-255.

16. Goldberg RB. Cardiovascular disease in diabetic patients. Med Clin North Am 2000;84:81-93.

17. Khaw KT, Wareham N, Luben R, Bingham S, Oakes S, Welch A, et al. Glycated hemoglobin, diabetes, and mortality in men in Norfolk cohort of European prospective investigation of cancer and nutrition (EPIC-Norfolk). BMJ 2001; 322: 15-18. 
18. Laakso M. Glycemic control and the risk for coronary heart disease in patients with non-insulin-dependent diabetes mellitus: the Finnish studies. Ann Intern Med 1996;124:127130 .

19. Eeg-Olofsson K, Cederholm J, Nilsson PM, Zethelius B, Svensson AM, Gudbjornsdóttir S, et al. Glycemic control and cardiovascular disease in 7,454 patients with type 1 diabetes: an observational study from the Group Swedish National Diabetes Register (NDR). Diabetes Care 2010; 33 : 1640-1646.

20. Selvin E, Steffes MW, Zhu H, Matsushita K, Wagenknecht L, Pankow J, et al. Glycated hemoglobin, diabetes, and cardiovascular risk in nondiabetic adults. $N$ Engl J Med 2010; 362: 800-811.

21. Wadsworth C, Wadsworth E. Efficacy of latex-agglutination and quantification methods for determination of C-reactive protein (CRP) in pediatric sera. Clinica Chimica Acta 1984; 138: 309-318.

22. Lee HJ, Her SH, Im YS, Won KY, Yoo SH, Kim DB, et al. Significance of Inflammatory Markers in Diabetic Patients with Stable Coronary Artery Disease. Korean J Intern Med 2009; 24: 212-219.

23. Libby $\mathrm{P}$, Ridker $\mathrm{P}$, Maseri A. Inflammation and atherosclerosis. Circulation 2002; 105: 1135-1143.

24. Glass CK, Witztum JL. Atherosclerosis: the road ahead. Cell 2001; 104: 503-516.

25. Ridker PM, Buring JE, Cook NR. C-reactive protein, the metabolic syndrome, and risk of incident cardiovascular events: an 8-year follow-up of 14719 initially healthy American women. Circulation 2003;107:391-397.

26. Ridker PM, Rifai N, Rose L, Buring JE, Cook NR. Comparison of C-reactive protein and low-density lipoprotein cholesterol levels in the prediction of first cardiovascular events. N Engl J Med 2002; 347: 1557-1565.

27. Rost NS, Wolf PA, Kase CS, Kelly-Hayes M, Silbershatz H, Massaro JM, et al. Plasma concentration of C-reactive protein and risk of ischemic stroke and transient ischemic attacks: the Framingham Study. Stroke 2001; 32: 25752579.
27. Albert CM, Ma J, Rifai N, Stampfer MJ, Ridker PM. Prospective study of C-reactive protein, homocysteine, and plasma lipid levels as predictors of sudden cardiac death. Circulation 2002; 105: 2595-2599.

29. Razban MM, Eslami M, Bagherzadeh A. The relationship between serum levels of hs-CRP and coronary lesion severity. Clujul Medical 2016; 89(3): 352-364.

30. Muhammad R, Masood A, Zaffar J, Butt U. Correlation of mean $\mathrm{HbA1c}$ levels with severity of coronary arteries disease in diabetics. Pak Heart J 2014; 47(4): 184-187.

31. Seyedian SM, Ahmadi F, Dabagh R, Davoodzadeh H. Relationship between high-sensitivity C-reactive protein serum levels and the severity of coronary artery stenosis in patients with coronary artery disease. ARYA Atheroscler 2016; 12(5): 231-237.

32. Berk BC, Weintraub WS, Alexander RW. Elevation of Creactive protein in "active" coronary artery disease. $A m \mathrm{~J}$ Cardiol 1990; 65: 168-172.

33. Liuzzo G, Biasucci LM, Gallimore JR, Grillo RL, Rebuzzi AG, Pepys MB, et al. The prognostic value of C-reactive protein and serum amyloid a protein in severe unstable angina. N Engl J Med 1994; 331: 417-424.

34. Haverkate F, Thompson SG, Pyke SD, Gallimore JR, Pepys MB. Production of C-reactive protein and risk of coronary events in stable and unstable angina: European Concerted Action on Thrombosis and Disabilities Angina Pectoris Study Group. Lancet 1997; 349: 462-466.

35. Tataru MC, Heinrich J, Junker R, Schulte H, von Eckardstein A, Assmann G, et al. C-reactive protein and the severity of atherosclerosis in myocardial infarction patients with stable angina pectoris. Eur Heart J 2000; 21: 1000-1008.

36. Masood A, Jafar SS, Akram Z. Serum high sensitivity Creactive protein levels and the severity of coronary atherosclerosis assessed by angiographic gensini score. $J$ Pak Med Assoc 2011; 61(4):325-327.

37. Schillinger M, Exner M, Amighi J, Mlekusch W, Sabeti S, Rumpold H, et al. Joint Effects of C-Reactive Protein and Glycated Hemoglobin in Predicting Future Cardiovascular Events of Patients With Advanced Atherosclerosis. Circulation 2003; 108: 2323-2328. 